\title{
Organic carbon and nutrient $(P, N)$ concentrations of water and sediment in several aquatic environment types of a Mediterranean coastal wetland (Empordà Wetlands, NE Iberian Peninsula)
}

\author{
S. Gascón*, D. Boix, J. Sala, X.D. Quintana
}

Institute of Aquatic Ecology and Department of Environmental Sciences, University of Girona, Campus de Montilivi, Facultat de Ciències, 17071 Girona, Spain.

\begin{abstract}
Total sediment and water organic carbon and nutrient (nitrogen and phosphorus) concentrations of different environment types of a Mediterranean coastal wetland (temporary and brackish, temporary and freshwater, semi-permanent and brackish, and permanent and brackish basins) were analysed during two hydroperiods. A nitrogen limitation was found for both sediment and water. The total organic carbon concentration of the water was significantly related to the water level, which varies throughout the hydroperiods. In contrast, the total organic carbon concentration of the sediment was not related to water level. However, significant differences in total organic carbon of the sediment were found between hydroperiods. On the other hand, total organic carbon of the sediment varied spatially, being higher in temporary brackish basins with lower sand content, and lower in permanent and semi-permanent brackish basins with higher sand content.
\end{abstract}

Keywords: water permanence, salinity, granulometry, water turnover, inter-annual variability

\section{Introduction}

Coastal ecosystems are highly fluctuating environments due to the exchange between waters of marine and inland origin. The intensity and frequency of these water inputs are determinant for the physical and chemical characteristics of these ecosystems. In their confinement hypothesis, Guelorget \& Perthuisot (1983) pointed out the importance of water turnover as the determinant factor in structuring communities and determining nutrient availability. In agreement with that, many studies of the physical and chemical characteristics of water and faunal composition note the importance of water turnover in coastal marshes (e.g. Valiela et al. 1978, Comín \& Valiela 1993, Gascón et al. 2005). Nutrient concentration and availability in Mediterranean coastal ecosystems are also highly determined by the lack of inputs during confinement situations. Water nutrient concentration may increase during flooding by external supplies, but also by concentration processes occurring during confinement situations, coinciding with water level decreases (Sou-

\footnotetext{
* Corresponding author : E-mail: stephanie.gascon@udg.es
}

chu et al. 1997, Quintana et al. 1998, Trobajo et al. 2002). Similarly, changes in sediment nutrient concentration may be related to flooding/confinement situations (Díaz-Espejo et al. 1999, Cotner et al. 2003) and their consequent changes in water level. On the other hand, differences in sediment nutrient concentration have also been related to physical properties of the sediment (Poach \& Faulkner 1998, Slomp et al. 1998). Therefore, water and sediment nutrient concentrations may respond to different factors determined by temporal or spatial patterns.

The aim of this study is to establish whether water and sediment nutrient concentrations in coastal wetlands are mainly determined by temporal patterns associated with water inputs or by spatial variability due to differences in water permanence and granulometry of the basins. For this proposal we selected the coastal wetlands of the Empordà Wetlands Natural Park. They are made up of several close basins with differences in water permanence and sediment granulometry (Gascón et al. 2005) and having a characteristic Mediterranean hydrology determined by sudden flooding events and long periods of confinement, which determine fluctuations in water level (Quintana 2002). 


\section{Material and methods}

\section{Study Site}

The study was undertaken in the coastal wetlands of the Empordà Wetlands Natural Park (NE Iberian Peninsula) during two hydroperiods (flooding cycles: from October 1997 to July 1998, and from September 1998 to July 1999). These coastal wetlands are free from tidal influence. The hydrology is characterised by sudden and irregular flooding (caused by rainfall, inputs from rivers or channels, and sea storms) followed by dry periods, when most of the basins become isolated and gradually dry out (Quintana 2002). Subterranean circulation of fresh and salt water is very active due to the abundance of sand deposits in the surface aquifer (Bach 1990).

Basins in the coastal wetlands are depressions located between sand bars where flood water accumulates. The depths vary greatly, depending on the flooding regime, but only occasionally reach more than $1 \mathrm{~m}$. Their beds are almost flat and scarcely vegetated.

Temporary brackish basins were the most common environment of these coastal wetlands, and were compared to other environment types also present in Mediterranean coastal wetlands, but less frequently found in our study site (Fig. $1 \&$ Table 1 ). Thus, the total organic carbon (TOC) and nutrients (N, P) of water and sediment from 4 environment types were compared: temporary brackish basins ( 4 basins), permanent brackish basins (1 basin), semi-permanent brackish basins ( 1 basin) and temporary freshwater basins (1 basin).

\section{Water and Sediment analyses}

Water level, temperature, oxygen saturation, salinity and $\mathrm{pH}$ were measured weekly in situ. Filtered and unfiltered water samples were taken monthly for analysis of dissolved inorganic nutrients $\left(\mathrm{NH}_{4}, \mathrm{NO}_{2}, \mathrm{NO}_{3}\right.$, and dissolved reactive $\mathrm{P})$ and total nutrients $(\mathrm{N}, \mathrm{P})$. Dissolved nutrients and total $\mathrm{N}$ and total $\mathrm{P}$ were measured according to Grasshoff et al. (1983). Total organic C was measured using a TOC analyser. Water-column samples were filtered (Whatman GF/C filters), and chlorophyll $a$ content was determined after extraction with $90 \%$ methanol (Talling \& Driver 1963). Monthly samples of sediment (two 5-cm-deep sediment cores with an inner diameter of $1.2 \mathrm{~cm}$ ) were collected and immediately frozen. Total $\mathrm{N}$ and $\mathrm{C}$ of the sediment were analysed using a CHNS-O analyser. Total organic $\mathrm{C}$ of the sediment was calculated by subtracting the total inorganic $\mathrm{C}$, obtained using a calcimetric method $\left(4 \mathrm{~h}\right.$ at $\left.450^{\circ} \mathrm{C}\right)$ and a CHNS-O analyser, from total C. Sediment chlorophyll $a$ and phaeopigments were extracted using methods described by

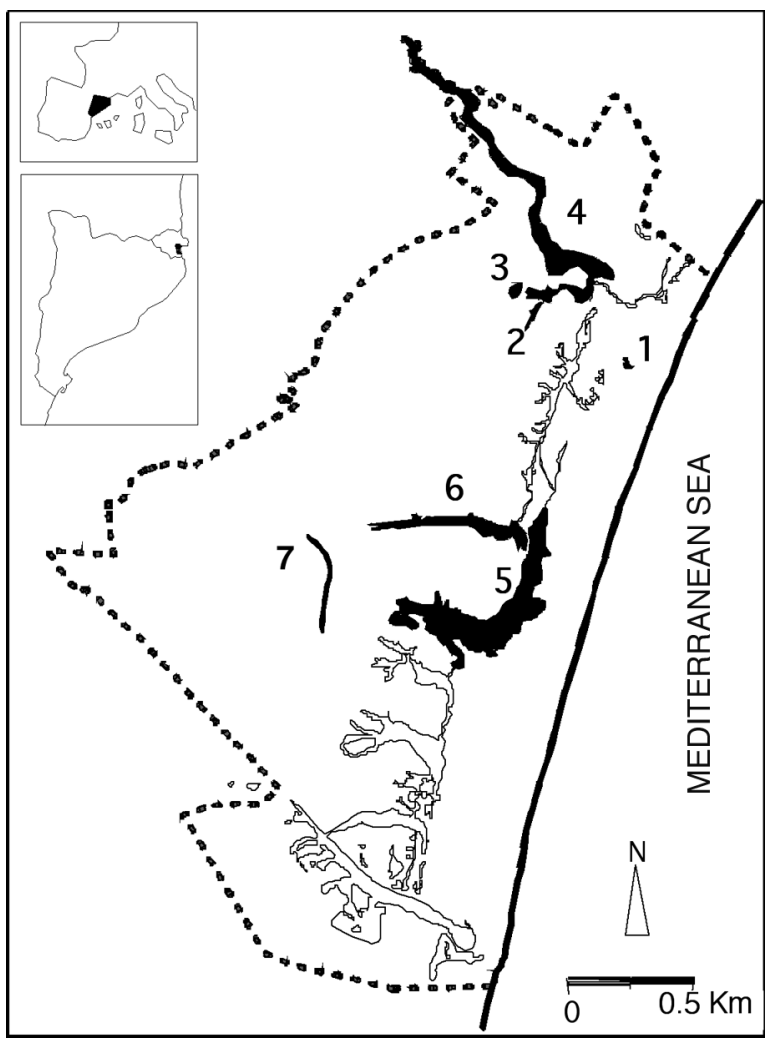

Fig. 1. Map of the study site, indicating the basins studied (black). Discontinuous line indicates the limit of the integral reserve of the Empordà Wetlands Natural Park. Legend: 1, 2, 3 and 6 correspond to temporary and brackish, 4 to semi-permanent and brackish, 5 to permanent and brackish, and 7 to temporary and freshwater basins.

Borrego \& Garcia-Gil (1994) and measured following Lorenzen (1967). Samples were obtained until the drying out of the temporary basins. Only one granulometric analysis in each basin was performed during the study.

\section{Statistical analysis}

Student's t-tests were performed (one analysis for each basin) in order to analyse water level differences between hydroperiods. Available weekly water level values were used for these tests, and when variance heterogeneity was detected (significant result after a Levene test) the Student's t-test was performed assuming variance heterogeneity.

A principal component analysis (PCA) was used as a descriptive tool to analyse data variability and patterns. Only data from monthly water samples obtained from the same day as sediment samples were used in this analysis. Thus, the dataset contained 65 samples and 19 variables, 
Table 1. Main physical and chemical characteristics of the studied environments. Median values in bold and coefficients of variation in brackets. Total number of samples are also indicated. * Indicates an environment type with artificial water inputs (Gascón et al. 2005).

\begin{tabular}{|c|c|c|c|c|c|}
\hline & 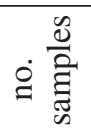 & $\begin{array}{c}\text { temporary } \\
\& \\
\text { brackish }\end{array}$ & $\begin{array}{l}\text { temporary } \\
\& \\
\text { freshwater* }\end{array}$ & $\begin{array}{c}\text { semi-permanent } \\
\& \\
\text { brackish }\end{array}$ & $\begin{array}{c}\text { permanent } \\
\& \\
\text { brackish }\end{array}$ \\
\hline Basins studied & & 4 & 1 & 1 & 1 \\
\hline Sand $(\%)$ & 7 & $\begin{array}{c}\mathbf{1 5 . 1} \\
(51.2)\end{array}$ & $\begin{array}{c}14.3 \\
-\end{array}$ & $\begin{array}{c}70.3 \\
-\end{array}$ & $\begin{array}{c}90.5 \\
-\end{array}$ \\
\hline Water level $(\mathrm{cm})$ & 465 & $\begin{array}{c}\mathbf{4 3 . 0} \\
(57.7)\end{array}$ & $\begin{array}{c}\mathbf{5 7 . 5} \\
(29.5)\end{array}$ & $\begin{array}{c}\mathbf{4 6 . 5} \\
(59.4)\end{array}$ & $\begin{array}{c}71.2 \\
(36.4)\end{array}$ \\
\hline Conductivity $\left(\mathrm{mS} \cdot \mathrm{cm}^{-1}\right)$ & 428 & $\begin{array}{c}\text { 31.1 } \\
(34.3)\end{array}$ & $\begin{array}{c}\mathbf{2 . 4} \\
(139.7)\end{array}$ & $\begin{array}{c}\mathbf{2 7 . 2} \\
(37.7)\end{array}$ & $\begin{array}{c}\mathbf{1 7 . 8} \\
(41.1)\end{array}$ \\
\hline Water temperature $\left({ }^{\circ} \mathrm{C}\right)$ & 421 & $\begin{array}{c}\mathbf{1 5 . 0} \\
(37.2)\end{array}$ & $\begin{array}{c}\mathbf{1 2 . 8} \\
(33.1)\end{array}$ & $\begin{array}{c}14.2 \\
(40.1)\end{array}$ & $\begin{array}{c}\mathbf{1 4 . 0} \\
(41.4)\end{array}$ \\
\hline Oxygen saturation (\%) & 417 & $\begin{array}{c}\mathbf{8 5 . 0} \\
(48.1)\end{array}$ & $\begin{array}{c}\mathbf{5 6 . 9} \\
(55.7)\end{array}$ & $\begin{array}{l}\mathbf{1 1 5 . 0} \\
(34.0)\end{array}$ & $\begin{array}{c}\mathbf{9 1 . 3} \\
(29.8)\end{array}$ \\
\hline \multicolumn{6}{|l|}{ Water } \\
\hline TOC $\left(\mathrm{mg} \cdot \mathrm{L}^{-1}\right)$ & 206 & $\begin{array}{c}\mathbf{1 5 . 4} \\
(102.2)\end{array}$ & $\begin{array}{c}\text { 11.0 } \\
(43.3)\end{array}$ & $\begin{array}{c}\mathbf{1 4 . 8} \\
(83.8)\end{array}$ & $\begin{array}{c}\mathbf{1 5 . 4} \\
(91.9)\end{array}$ \\
\hline $\mathrm{TN}\left(\mathrm{mg} \cdot \mathrm{L}^{-1}\right)$ & 125 & $\begin{array}{c}\mathbf{1 . 5 5} \\
(102.6)\end{array}$ & $\begin{array}{c}\mathbf{1 . 2 8} \\
(76.2)\end{array}$ & $\begin{array}{c}\mathbf{2 . 9 3} \\
(51.9)\end{array}$ & $\begin{array}{c}\mathbf{1 . 4 3} \\
(56.2)\end{array}$ \\
\hline $\mathrm{TP}\left(\mathrm{mg} \cdot \mathrm{L}^{-1}\right)$ & 124 & $\begin{array}{c}\mathbf{0 . 1 4} \\
(186.8)\end{array}$ & $\begin{array}{c}\mathbf{0 . 0 8} \\
(96.5)\end{array}$ & $\begin{array}{c}\text { 0.28 } \\
(92.9)\end{array}$ & $\begin{array}{c}\mathbf{0 . 1 1} \\
(71.4)\end{array}$ \\
\hline TOC:TN & 108 & $\begin{array}{c}\mathbf{1 0 . 9} \\
(94.8)\end{array}$ & $\begin{array}{c}\mathbf{8 . 7} \\
(49.2)\end{array}$ & $\begin{array}{c}\mathbf{9 . 2} \\
(78.1)\end{array}$ & $\begin{array}{c}\mathbf{1 0 . 6} \\
(63.5)\end{array}$ \\
\hline TOC:TP & 108 & $\begin{array}{c}\mathbf{2 7 0 . 7} \\
(174.6)\end{array}$ & $\begin{array}{c}\mathbf{2 1 0 . 3} \\
(130.8)\end{array}$ & $\begin{array}{c}\mathbf{1 6 4 . 8} \\
(115.1)\end{array}$ & $\begin{array}{c}\mathbf{3 4 4 . 3} \\
(94.10)\end{array}$ \\
\hline TN:TP & 123 & $\begin{array}{c}\mathbf{2 5 . 6} \\
(82.3)\end{array}$ & $\begin{array}{c}29.7 \\
(94.1)\end{array}$ & $\begin{array}{c}\mathbf{1 9 . 0} \\
(65.2)\end{array}$ & $\begin{array}{c}\mathbf{2 9 . 2} \\
(74.2)\end{array}$ \\
\hline \multicolumn{6}{|l|}{ Sediment } \\
\hline TOC $\left(\mathrm{g} \cdot \mathrm{kg}^{-1}\right)$ & 142 & $\begin{array}{c}\mathbf{2 9 . 5} \\
(38.8)\end{array}$ & $\begin{array}{c}\mathbf{1 5 . 3} \\
(26.7)\end{array}$ & $\begin{array}{c}7.3 \\
(54.9)\end{array}$ & $\begin{array}{c}\mathbf{5 . 6} \\
(70.6)\end{array}$ \\
\hline $\mathrm{TN}\left(\mathrm{g} \cdot \mathrm{kg}^{-1}\right)$ & 146 & $\begin{array}{c}\mathbf{2 . 9 5} \\
(29.5)\end{array}$ & $\begin{array}{c}\mathbf{1 . 7 4} \\
(20.1)\end{array}$ & $\begin{array}{c}\mathbf{0 . 7 9} \\
(20.2)\end{array}$ & $\begin{array}{c}\mathbf{0 . 4 6} \\
(85.3)\end{array}$ \\
\hline $\mathrm{TP}\left(\mathrm{g} \cdot \mathrm{kg}^{-1}\right)$ & 136 & $\begin{array}{c}\mathbf{0 . 7 4} \\
(21.5)\end{array}$ & $\begin{array}{c}\mathbf{0 . 7 6} \\
(13.2)\end{array}$ & $\begin{array}{c}\mathbf{0 . 4 2} \\
(24.4)\end{array}$ & $\begin{array}{c}\mathbf{0 . 2 6} \\
(40.2)\end{array}$ \\
\hline TOC:TN & 142 & $\begin{array}{l}\mathbf{1 2 . 6} \\
(21.0)\end{array}$ & $\begin{array}{c}\mathbf{1 0 . 0} \\
(22.3)\end{array}$ & $\begin{array}{c}\mathbf{1 2 . 9} \\
(47.2)\end{array}$ & $\begin{array}{c}\mathbf{1 0 . 9} \\
(72.3)\end{array}$ \\
\hline TOC:TP & 133 & $\begin{array}{c}\mathbf{9 5 . 9} \\
(36.1)\end{array}$ & $\begin{array}{c}\mathbf{5 1 . 8} \\
(34.5)\end{array}$ & $\begin{array}{c}\mathbf{4 7 . 2} \\
(61.1)\end{array}$ & $\begin{array}{c}\mathbf{4 8 . 4} \\
(70.3)\end{array}$ \\
\hline TN:TP & 136 & $\begin{array}{c}\mathbf{8 . 2} \\
(25.9)\end{array}$ & $\begin{array}{c}\mathbf{5 . 0} \\
(23.7)\end{array}$ & $\begin{array}{c}\mathbf{4 . 2} \\
(36.3)\end{array}$ & $\begin{array}{c}\mathbf{3 . 6} \\
(65.4)\end{array}$ \\
\hline
\end{tabular}

after suppressing samples with missing values. Eleven variables were included from water (conductivity, temperature, water level, ammonium, nitrite, nitrate, dissolved reactive $\mathrm{P}$, total phosphorus, total nitrogen, total organic carbon, chlorophyll $a$ ) and 8 variables were included from sediment (sand content, clay content, silt content, total phosphorus, total nitrogen, total organic carbon, chlorophyll $a$ and phaeopigments). Sand, clay 
and silt content are ordinal variables, and since we only had one value for each basin the values were repeated for all samples of the same basin. All variables except sand, silt and clay content, were $\log$ transformed $\left(\log _{10}[\mathrm{x}+1]\right)$. A correlation matrix was used as an association matrix, since variables were measured in very different units (Quinn \& Keough 2002). PCA analysis was carried out using CANOCO 4.5 (ter Braak \& Šmilauer 2002).

Pearson correlation analyses were performed in order to establish the strength of the relationships between total organic carbon (TOC), total nitrogen (TN) and total phosphorus (TP). Analyses of Covariance (ANCOVA) were used to test whether environment type or hydroperiod were the factors that influenced TOC concentration (previously log transformed using the natural logarithm), as an estimation of nutrient assimilation, in both water and sediment systems. The water level was used as covariable, since the concentration of dissolved nutrient inputs in these coastal wetlands has been related to water inputs (Quintana et al. 1998). The analyses of covariance started with the most complex model, introducing all possible interactions (including interactions of covariables $\times$ factors, following García-Berthou \& MorenoAmich (1993)). Then, the model was simplified by removing non significant interactions $(P>0.10)$ to increase statistical power that would otherwise be seriously compromised.

\section{Results}

Basins with higher water permanence also had higher sand content (basin 4 and 5), and so water permanence covariated with sand content in the study site. Water variables showed high coefficients of variation indicating high environmental variability related to hydrological fluctuations. The temporary freshwater basin had the lowest conductivity values but also the highest coefficient of variation of conductivity. Moreover, this environment type had the lowest coefficient of variation of water level. In water the highest median concentration of total nutrients and organic carbon was found in the semi-permanent brackish basin, while temporary brackish basins had the highest coefficient of variation of nutrient and organic carbon (Table 1). This is also true when each basin of this environment type is taken into consideration separately (for example, coefficient of variation for total phosphorus was 161.9, 139.3, 164.6, and 71.3 for basins $1,2,3$, and 6 , respectively). In contrast, the highest median concentration of total nutrients and organic carbon in sediment was obtained in temporary brackish basins, with lower sand content, while the permanent brackish basin, with higher sand content, had the highest coefficients of variation (Table 1). Note that median values of total organic carbon of the sediment were, for all environment types, less than $30 \mathrm{~g} / \mathrm{kg}(\sim 3 \%)$. Moreover, all analysed samples had values lower than $100 \mathrm{~g} / \mathrm{kg}(\sim 10 \%)$ of total organic carbon.

TheTOC:TNmolar ratio obtained for each environment type had similar values for water and sediment (ranging from 8.7 to 12.9). The TOC:TP and TN:TP molar ratios had higher values, for all environments, in water samples (Table 1), which means that in relation to organic carbon or nitrogen content, there is more phosphorus content in sediment than in water. Total organic carbon was significantly related to total phosphorus and total nitrogen in both sediment and water samples, but the correlation coefficient $(R)$ was higher between total organic carbon and total nitrogen than between total organic carbon and total phosphorus in water and in sediment (Fig. 2). Additionally, spatial segregation of sediment organic carbon and nutrient concentration was detected. Thus, nutrient concentration and organic carbon concentrations were related to differences in water permanence and sand content, since samples from permanent and semi-permanent basins with higher sand content had lower nutrient and organic carbon concentration (Fig. 2).

Significant differences in the basins' water levels were observed between the studied hydroperiods (Table 2). The first hydroperiod (from October 1997 to July 1998) had significant higher water levels than the second hydroperiod (from September 1998 to July 1999). Thus, the first hydroperiod has been considered as a wet hydroperiod and the second hydroperiod as a dry hydroperiod.

The pattern of variation along time of water nutrients are conditioned by incidents of water entry and drying (Fig. 3). The higher increases in dissolved nutrients occurred at the start of hydroperiods just after the flood of the basins (Fig. 3). In contrast, total nutrients had two periods with high values, one at the start and one at the end of the hydroperiods, the latter coinciding with high values of total organic carbon concentration (Fig. 3). On the other hand, sediment nutrients and sediment organic carbon did not show a temporal variation related to water level fluctuation (Fig. 4). The main differences observed are more conditioned by the granulometry and water permanence of each environment type (Fig. 4). Thus, temporary basins which had low sand percentage (brackish or freshwater) always had higher nutrient and organic carbon concentration (Fig. 4 and Table 1).

The ANCOVA results for sediment samples showed that the total organic carbon of the sediment did not covary with water level, since a non significant result was obtained for the "water level" covariable. Thus, we 
WATER
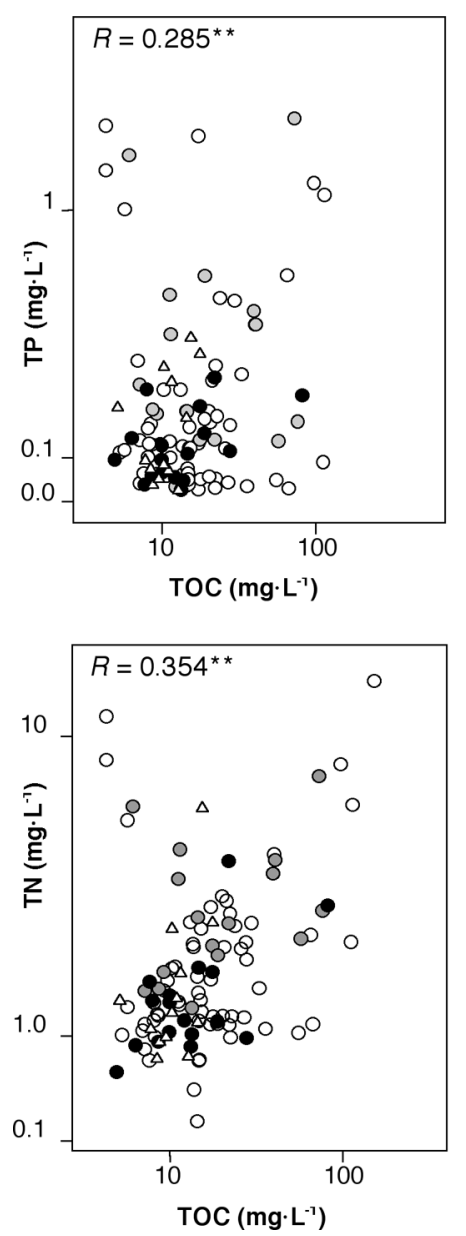

SEDIMENT
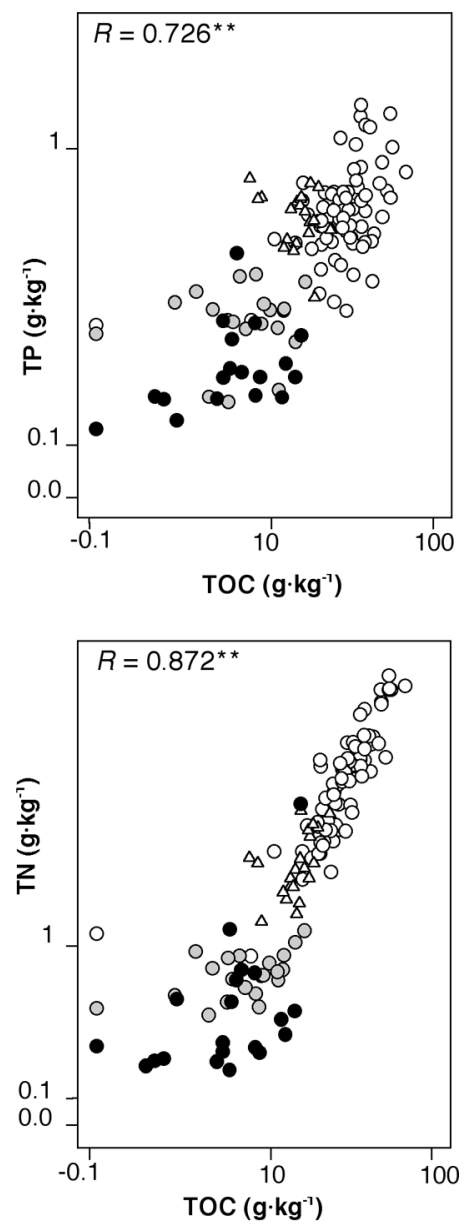

Fig. 2. Correlation between total organic carbon (TOC) and both total nitrogen (TN) and total phosphorus (TP), in water and sediment samples. Asterisks indicate significant correlation at $P<0.01$. Open circles correspond to temporary brackish basins, open triangles to temporary freshwater basin, shaded circles to semi-permanent brackish basin, and solid circles to permanent brackish basin.

decided not to take this covariable into consideration, and we carried out an ANOVA. The ANOVA results showed significant differences on total organic carbon concentration among environment types $\left(F_{3,137}=89.4\right.$; $P<0.01)$ and hydroperiods $\left(F_{1,137}=5.55 ; P<0.05\right)$. The sediment had significantly lower total organic carbon concentrations during the wet hydroperiod than during the dry one (Fig. 5). The temporary brackish basins had the highest total organic carbon concentrations followed by the temporary freshwater basin, and finally the semipermanent and permanent brackish basins had similar and lower values (Fig. 6). No significant interaction between environment type and hydroperiod was obtained.
In water, total organic carbon concentration covaried with water level (Table 3). Moreover, the ANCOVA analysis showed significant results for the two factors, environment type and hydroperiod, as well as for the interaction between hydroperiod and water level. In general, all environment types had higher total organic carbon concentration during the dry hydroperiod (Fig. 7). A significant negative relation was found between water level and total organic carbon, which had a lower slope and adjustment in the dry hydroperiod than in the wet one (Fig. 8). Nevertheless, the lower partial eta squared terms indicated a lower importance of the factors and interaction against the covariable (Table 3). Thus, the highest partial eta squared of the water level showed that the total 

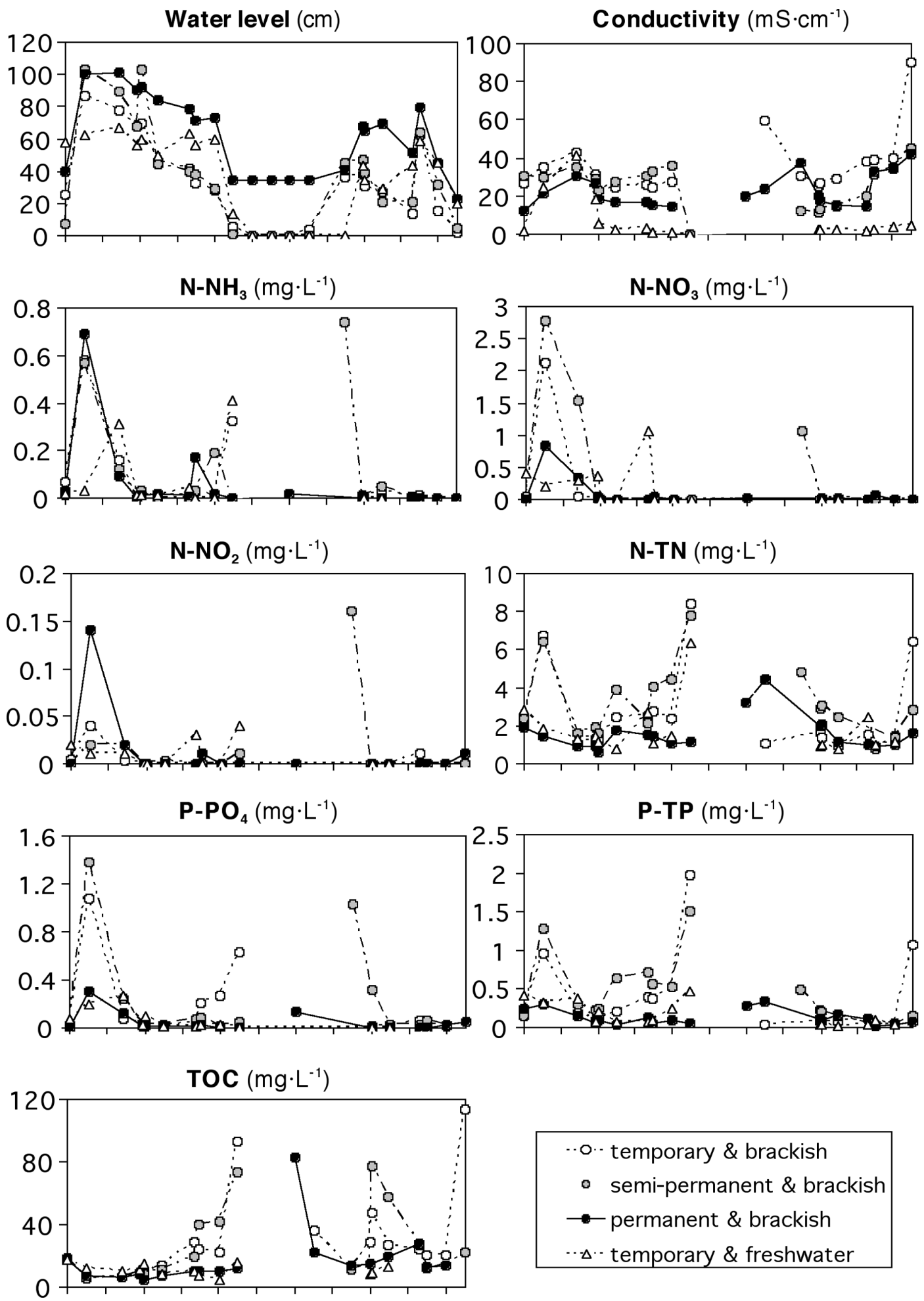

Fig. 3. Temporal pattern in water of level, conductivity, total organic carbon, and dissolved and total nutrients for each environment type. 


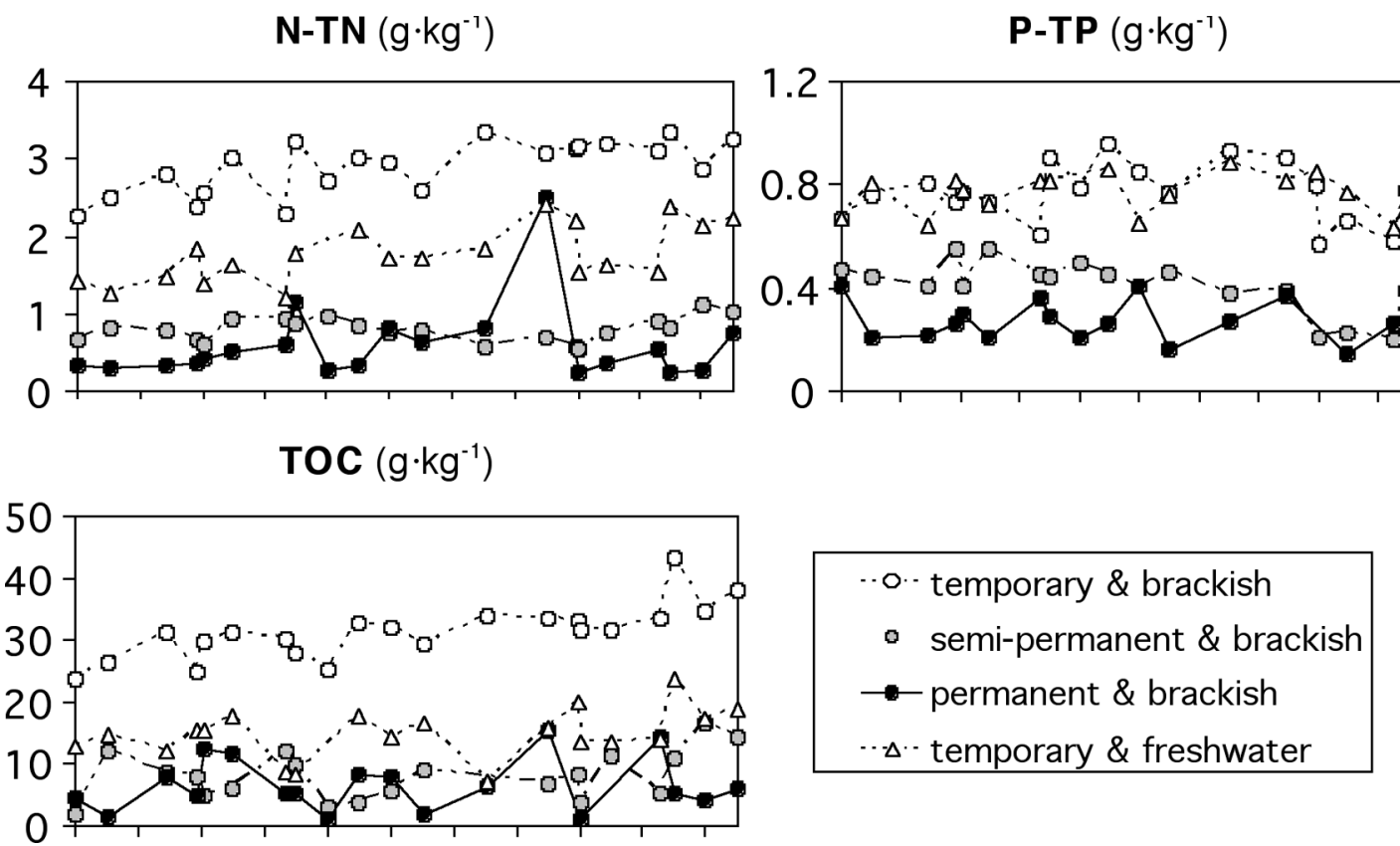

Fig. 4. Temporal pattern in sediment of total nutrients and total organic carbon for each environment type.

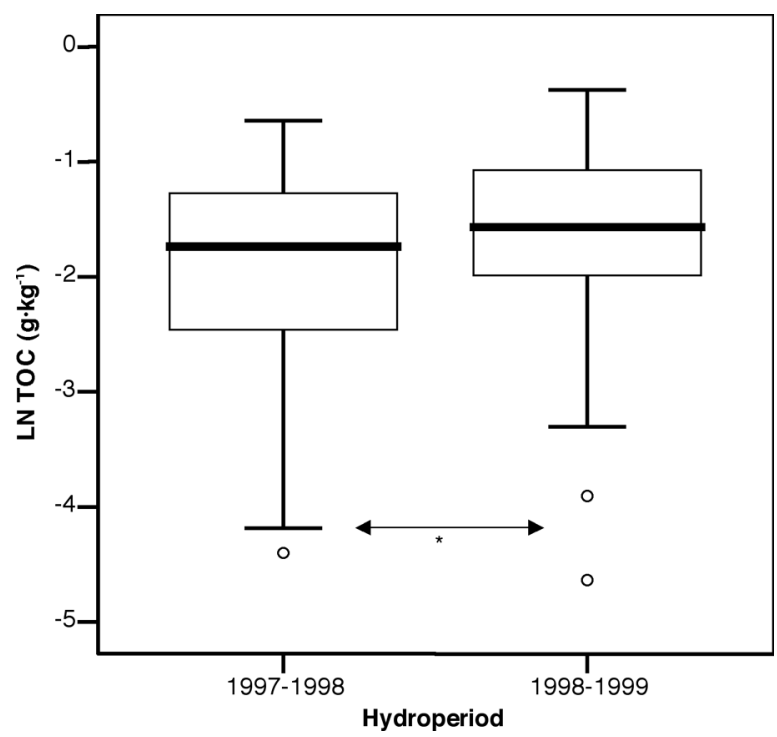

Fig. 5. Box plot of sediment total organic carbon values (natural logarithm) during the wet (1997-1998) and dry (1998-1999) hydroperiod. Asterisk indicates $P<0.05$.

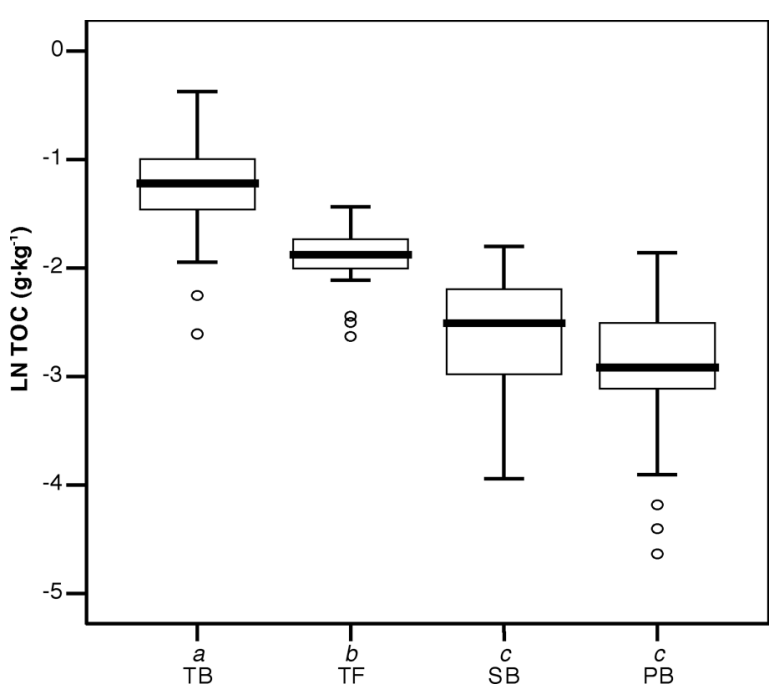

Fig. 6. Box plot of sediment total organic carbon values (natural logarithm) for each environment type, showing anomalous values (o). Legend: "TB" corresponds to temporary and brackish, "TF" to temporary and freshwater, "SB" to semi-permanent and brackish, and "PB" to permanent and brackish basins. Environment types with the same italic letter (" $a$ ", " $b$ " or " $c ")$ do not differ significantly $(P>0.05$, Bonferroni post-hoc tests). 
Table 2. Mean water level $(\mathrm{cm}) \pm$ standard deviation, and in brackets number of cases, for each basin and hydroperiod studied (H1: 1997-1998; H2: 1998-1999). Student's t-test results are also shown. $\dagger$ indicates that the Student's t-test has been performed assuming variance heterogeneity, since the Levene test is significant.

\begin{tabular}{|c|c|c|c|c|c|}
\hline \multirow{2}{*}{ Basin } & \multirow{2}{*}{ Hydroperiod } & \multirow{2}{*}{ Water level } & \multicolumn{3}{|c|}{ Student's t-test } \\
\hline & & & $t$ & $\mathrm{df}$ & $p$ \\
\hline \multirow{2}{*}{1} & H1 & $58.1 \pm 34.2 ;(37)$ & \multirow{2}{*}{3.651} & \multirow{2}{*}{58.8} & \multirow{2}{*}{$0.001 \dagger$} \\
\hline & $\mathrm{H} 2$ & $33.8 \pm 19.3 ;(29)$ & & & \\
\hline \multirow{2}{*}{2} & H1 & $65.5 \pm 31.1 ;(37)$ & \multirow{2}{*}{4.868} & \multirow{2}{*}{61.5} & \multirow{2}{*}{$<0.001 \dagger$} \\
\hline & $\mathrm{H} 2$ & $34.1 \pm 20.6 ;(27)$ & & & \\
\hline \multirow{2}{*}{3} & H1 & $59.1 \pm 32.0 ;(38)$ & \multirow{2}{*}{4.362} & \multirow{2}{*}{61.6} & \multirow{2}{*}{$<0.001 \dagger$} \\
\hline & $\mathrm{H} 2$ & $31.2 \pm 19.4 ;(27)$ & & & \\
\hline \multirow{2}{*}{4} & H1 & $66.1 \pm 39.3 ;(38)$ & \multirow{2}{*}{3.703} & \multirow{2}{*}{55.1} & \multirow{2}{*}{$<0.001 \dagger$} \\
\hline & $\mathrm{H} 2$ & $39.3 \pm 18.1 ;(28)$ & & & \\
\hline \multirow{2}{*}{5} & H1 & $84.3 \pm 24.9 ;(40)$ & \multirow{2}{*}{6.112} & \multirow{2}{*}{75} & \multirow{2}{*}{$<0.001$} \\
\hline & $\mathrm{H} 2$ & $54.1 \pm 17.5 ;(37)$ & & & \\
\hline \multirow{2}{*}{6} & H1 & $54.0 \pm 20.1 ;(38)$ & \multirow{2}{*}{6.277} & \multirow{2}{*}{63} & \multirow{2}{*}{$<0.001$} \\
\hline & $\mathrm{H} 2$ & $25.7 \pm 14.4 ;(27)$ & & & \\
\hline \multirow{2}{*}{7} & $\mathrm{H} 1$ & $58.7 \pm 15.9 ;(39)$ & \multirow{2}{*}{4.051} & \multirow{2}{*}{60} & \multirow{2}{*}{$<0.001$} \\
\hline & $\mathrm{H} 2$ & $43.0 \pm 12.6 ;(23)$ & & & \\
\hline
\end{tabular}

Table 3. Analysis of covariance (ANCOVA) for water, using water level (WL) as covariable, hydroperiod (HYD) and environment (ENV) as factors, and natural logarithm of total organic carbon as dependent variable. Partial eta squared values, as a measure of effect size, are also shown.

\begin{tabular}{ccccc}
\hline $\begin{array}{c}\text { Source } \\
\text { of variation }\end{array}$ & df & $F$ & $P$ & $\begin{array}{c}\text { Partialeta } \\
\text { squared }\end{array}$ \\
\hline WL & 1,198 & 63.965 & $<0.001$ & 0.244 \\
HYD & 1,198 & 6.054 & 0.015 & 0.030 \\
ENV & 3,198 & 5.498 & 0.001 & 0.077 \\
WL $\times$ HYD & 1,198 & 7.551 & 0.007 & 0.037 \\
\hline
\end{tabular}

organic carbon of water had a temporal pattern throughout the hydroperiods due mainly to water level fluctuations (Table 3).

The relation between water and sediment variables was analysed by means of PCA. The first two components explained $49.6 \%$ of the variance (Fig. 9). The PCA showed that water variables were highly related among themselves, and were almost independent of sediment variables, since the position of water variable vectors were almost orthogonal to the position of sediment variable vectors (Fig. 9). The PCA result is in accordance with the ANCOVA results. Thus, the independence of total organic carbon of the sediment and water level found in the ANCOVA was also shown by the position of the variables in the PCA, which were almost orthogonally distributed (Fig. 9). Moreover, the relationship between water level and total organic carbon of water demonstrated by the ANCOVA was shown by the opposing directions of the total organic carbon and water level arrows in the PCA (Fig. 9).

\section{Discussion}

The low total organic carbon concentration in sediments of Empordà coastal wetlands allowed them to be characterised as mineral, since all samples analysed had concentrations below 12\% (Mitsch \& Gosselink 1993). The sediment nutrient concentrations were lower than those described for the North Sea (Slomp et al. 1998) and were placed in the low part of the ranges described for coastal lagoons (López et al. 1996), some deltas (Forés \& González 1988, Poach \& Faulkner 1998), and Mediter- 


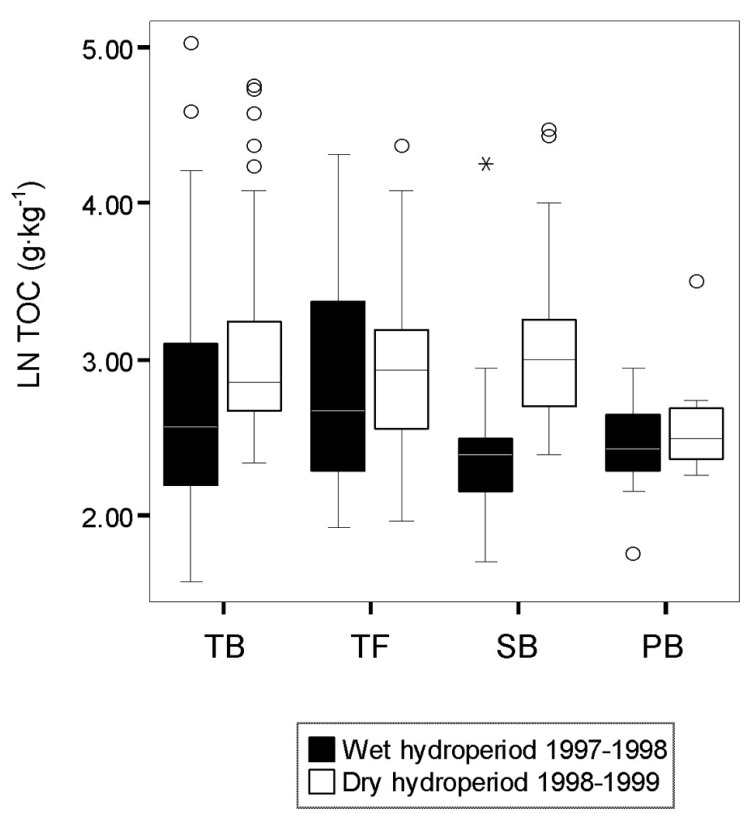

Fig. 7. Box plot of total organic carbon values of water (natural logarithm) for each environment type and hydroperiod, showing extreme (*) and anomalous values (o). Legend: "TB" corresponds to temporary and brackish systems, "TF" to temporary and freshwater, "SB" to semi-permanent and brackish, and "PB" to permanent and brackish systems.

ranean coastal wetlands (Bonanni et al. 1992, Groot \& Golterman 1993, López \& Lluch 2000). High nutrient concentration in sediment has been noted in other coastal wetlands, as a long term consequence of nearby human activities. These activities mainly changed water regimes, increasing continental water inputs and modifying the exchange with marine waters (Bonanni et al. 1992, Mitsch \& Gosselink 1993, Gopal \& Junk 2000). In contrast, Empordà coastal wetlands have a characteristic hydrology with sudden water inputs, generally of marine origin, and long confinement periods without water inputs, ending with a dry period, when most of the basins remain dry. In similar fluctuating systems flooding events have been associated with nutrient recycling processes (Serrano et al. 1999), and dry periods with mineralization and wind desquamation processes (Groot \& Wicjk 1993). Furthermore, it has been described that a $\mathrm{C}: \mathrm{N}$ ratio lower than 20 allows a better degradation of organic matter (Golterman 1984), which also might contribute to the mineral character of the sediment.

In sediment of studied basins, the observed values of the TN:TP ratio (less than 15) and the better correlation between total nitrogen and total organic carbon than between total phosphorus and total organic carbon indi-

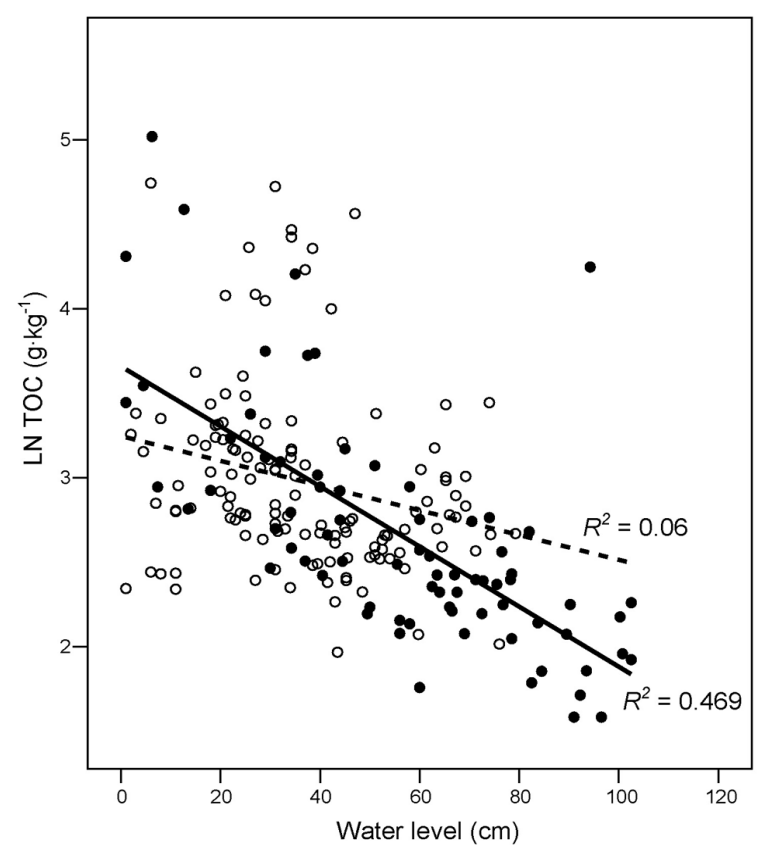

Fig.8. Regression between water level and total organic carbon of water, showing samples and their adjustment to a linear model in the wet (solid circles and solid line) and dry (open circles and dashed line) hydroperiod.

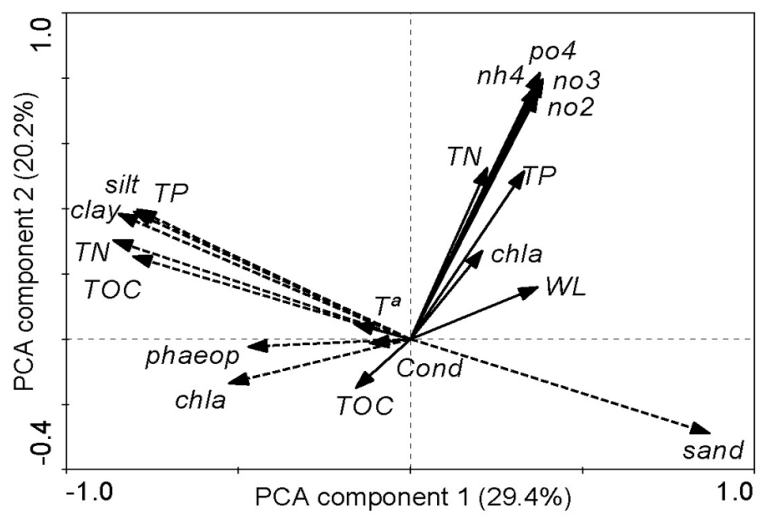

Fig. 9. Representation of variables in the PCA component space $[1,2]$. Dashed arrows correspond to sediment variables and solid arrows to water variables. In brackets, the percentage of variance explained for each component. Variables are: sand content, clay content, silt content, total phosphorus (TP), total nitrogen (TN), total organic carbon (TOC), chlorophyll $a$ (chla) and phaeopigments (phaeop), conductivity (Cond), temperature $\left(\mathrm{T}^{\mathrm{a}}\right)$, water level (WL), ammonium (nh4), nitrite (no2), nitrate (no3), dissolved reactive $\mathrm{P}$ (po4). 
cate a potential nitrogen limitation (Levine \& Schindler 1992). The cause of this may be denitrification, which is a frequent process in coastal lagoons (Golterman 1984, Kemp et al. 1990), especially in those with low water turnover (Comín \& Valiela 1993, Quintana et al. 1998). Denitrification processes imply losses of nitrate and other inorganic forms of nitrogen if nitrification processes are important. However, total nitrogen concentration could be compensated by the fixation of atmospheric nitrogen. The N:Pratio of inorganic forms (DIN:SRP), in the Empordà coastal wetlands were mainly below 16 (Quintana et al. 1998, Quintana et al. 1999, our study) and coincided with those described to allow a nitrogen fixation process (Flett et al. 1980). Moreover, in the studied basins cyanobacteria were abundant among phytoplanktonic organisms (Quintana \& Moreno-Amich 2002). Therefore, the nitrogen limitation found in the sediments of the basins can also be extended to water, for the phytoplankton without the capacity to fix atmospheric nitrogen. The higher TN:TP ratio in the water could be caused by nitrogen fixing cyanobacteria. Mediterranean environments have a high hydrological variability (Comín 1989), which may make it difficult to find differences even with a long study period (several years). However, and despite the short period studied (only 2 hydrological cycles), significant differences in total organic carbon for both water and sediment were detected between the hydroperiods studied, which had significant differences in water inputs.

The total organic carbon concentration of the water of the Empordà coastal wetlands was significantly related to water level, which varies throughout the hydroperiods. This relationship may be due to a simple concentration effect, since less confined situations, with high water inputs and hence high water levels, had lower total organic carbon concentrations. This is in agreement with previous studies developed in Empordà wetlands which put in evidence the difficulty in discriminating between the increase of nutrients caused by water inputs from that caused by simple concentration processes by water evaporation during confinement situations (Quintana et al. 1998, Trobajo et al. 2004). On the other hand, total organic carbon of the sediment varied among environment types, being higher in temporary brackish basins with lower sand content, and lower in permanent and semi-permanent brackish basins with higher sand content. Due to the existent covariation of water permanence and granulometry observed in the study site, it is not possible to identify the factor responsible for the observed differences in total organic carbon concentration in the sediment. However, it is well known that the nutrient content in sediments of fine particles, such as clay and silt, tends to be higher than that observed in sediments of coarse particles, such as sand (Poach \& Faulkner 1998, Slomp et al. 1998, Díaz-Espejo et al. 1999). In any case, both water permanence and granulometry are spatial characteristics of the studied environment types, and hence, total organic carbon concentration of the sediment was only determined by spatial patterns.

In summary, variability in water nutrients and organic carbon is mainly related to temporal changes while in sediment it is related to spatial heterogeneity. This relationship is also observed in the faunal communities that inhabit the same coastal wetlands, where the plankton community varies throughout the hydroperiod (Brucet et al. 2005), but the benthic community varies among the different environments of these wetlands (Gascón et al. 2005). Thus, the pattern observed for organisms is also valid for nutrients.

\section{Acknowledgements}

We are grateful to Carles Alcaraz for valuable advice and comments on the statistical analyses. This work was supported by a grant from the Comisión de Investigación Científica y Técnica (CICYT), Programa de Recursos Naturales (ref. CGL2004-05433 / BOS).

\section{References}

Bach J. 1990. - L'ambient hidrològic de la plana litoral de l'Alt Empordà (NE. Catalunya). Ph. D. thesis, Autonomous University of Barcelona, Spain.

Bonanni P., Caprioli R., Ghiara E., Mignuzzi C., Orlandi C., Paganin G. \& Monti A. 1992. - Sediment and interstitial water chemistry of the Orbetello lagoon (Grosseto, Italy); nutrient diffusion across the water-sediment interface. Hydrobiologia, 235/236, 553-568.

Borrego C.M. \& Garcia-Gil L.J. 1994. - Separation of bacteriochlorophyll homologues from green photosynthetic sulfur bacteria by reversed-phase HPLC. Photosynth. Res., 41, 157-163.

Brucet S., Boix D., López-Flores R., Badosa A., Moreno-Amich R. \& Quintana X.D. 2005. - Zooplankton structure and dynamics in permanent and temporary Mediterranean salt marshes: taxonbased and size-based approaches. Arch. Hydrobiol., 154, 19-40.

Comín F.A. 1989. - Els sistemes aquàtics costaners. Pages 442-464 in Sistemes naturals. Història Natural dels Països Catalans, 14. Terrades J., Prat N., Escarré A. \& Margalef R. (eds). Enciclopèdia Catalana, Barcelona.

Comín F.A. \& Valiela I. 1993. - On the controls of phytoplankton abundance and production in coastal lagoons. J. Coastal. Res., 9, 895-906.

Cotner J.B., Suplee M.W., Chen N.W. \& Shormann D.E. 2003. Nutrient, sulphur and carbon dynamics in a hypersaline lagoon. Estuar. Coast. Shelf S., 59, 639-652.

Díaz-Espejo A., Serrano L. \& Toja J. 1999. - Changes in sediment phosphate composition of seasonal ponds during filling. Hydrobiologia, 329, 21-28.

Flett R.J., Schindler D.W., Hamilton R.D. \& Campbell N.E.R. 1980. - Nitrogen fixation in Canadian precambrian shield lakes. Can. J. Fish. Aquat. Sci., 37, 494-505. 
Forés E. \& González S. 1988. - Heterogeneidad espaciotemporal del sedimento de los arrozales del delta del Ebro (NE de España). Oecologia Aquatica, 9, 125-135.

García-Berthou E. \& Moreno-Amich R. 1993. - Multivariate analysis of covariance in morphometric studies of the reproductive cycle. Can. J. Fish. Aquat. Sci., 50, 1394-1399.

Gascón S., Boix D., Sala J. \& Quintana X.D. 2005. - Variability of benthic assemblages in relation to the hydrological pattern in Mediterranean salt marshes (Empordà wetlands, NE Iberian Peninsula). Arch. Hydrobiol., 163, 163-181.

Golterman H.L. 1984. - Sediments, modifying and equilibrating factors in the chemistry of freshwater. Verh. Internat. Verein. Limnol., 22, 23-59.

Gopal B. \& Junk W.J. 2000. - Biodiversity in wetlands: an introduction. Pages 1-10 in Biodiversity in wetlands: assessment, function and conservation. Volume 1. Gopal B., Junk W.J. \& Davis J.A. (eds). Backhuys Publishers, Leiden.

Grasshoff K., Ehrhardt M. \& Kremling K. 1983. - Methods of seawater analysis. Verlag Chemie, Weinheim, $418 \mathrm{p}$.

Groot C.J.de \& Wijck C.van 1993. - The impact of desiccation of a freshwater marsh (Garcines Nord, Camargue, France) on sediment-water-vegetation interactions. Hydrobiologia, 252, 8394.

Groot C.J.de \& Golterman H.L. 1993. - On the presence of organic phosphate in some Camargue sediments: evidence for the importance of phytate. Hydrobiologia, 252, 117-126.

Guelorget O. \& Perthuisot J.P. 1983. - Le domaine paralique: Expressions géologiques, biologiques et économiques du confinement. Travaux du laboratoire de Géologie 16. Presses de l'École Normale Supérieure, París, 136 p.

Kemp W.M., Sampou P., Caffrey J., Mayer M., Henriksen K. \& Boynton W.R. 1990. - Ammonium recycling versus denitrification in Chesapeake Bay sediments. Limnol. Oceanogr., $35,1545-1563$

Levine S.N. \& Schindler D.W. 1992. - Modification of the N:P ratio in lakes by in situ processes. Limnol. Oceanogr., 37, 917-935.

López P. \& Lluch X. 2000. - Sediment geochemistry of a meromictic coastal lagoon "Es Cibollar" (Mallorca, Spain). Limnetica, 18, 15-27.

López P., Lluch X., Vidal M. \& Morguí J.A. 1996. - Adsorption of phosphorus on sediments of the Balearic Islands (Spain) related to their composition. Estuar. Coast. Shelf S., 42, 185-196.

Lorenzen C.J. 1967. - Determination of chlorophyll and Pheopigments: Spectrophotometric Equations. Limnol. Oceanogr., 12, 343-346.

Mitsch W.J. \& Gosselink J.G. 1993. - Wetlands. New York: Van Nostrand Reinhold.

Poach M.E. \& Faulkner S.P. 1998. - Soil phosphorus characteristics of created and natural wetlands in the Atchafalaya Delta, LA. Estuar. Coast. Shelf S., 46, 195-203.
Quinn G.P. \& Keough M.J. 2002. - Experimental Design and Data Analysis for Biologists. Cambridge University Press, Cambridge. $537 \mathrm{p}$.

Quintana X.D., Moreno-Amich R. \& Comín F.A. 1998. - Nutrient and plankton dynamics in a Mediterranean salt marsh dominated by incidents of flooding. Part 1: Differential confinement of nutrients. J. Plankton Res., 20, 2089-2107.

Quintana X.D., Suñer L1., Trobajo R., Gascón S. \& Moreno-Amich R. 1999. - Nutrientes y renovación del agua en Aiguamolls de l'Empordà (NE de la península Ibérica). Uso potencial de agua residual para la inundación de zonas húmedas. Limnetica, 16, 4959.

Quintana X.D. 2002. - Estimation of water circulation in a Mediterranean salt marsh and its relationship with flooding causes. Limnetica, 21, 25-35.

Quintana X.D. \& Moreno-Amich R. 2002. - Phytoplankton composition of Empordà salt marshes, Spain and its response to freshwater flux regulation. J. Coastal. Res., 36, 581-590.

Serrano L., Burgos M.D., Díaz-Espejo A. \& Toja J. 1999. Phosphorus inputs to wetlands following storm events after drought. Wetlands, 9, 318-326.

Slomp C.P., Malschaert J.F.P. \& Raaphorst W.van. 1998. - The role of adsorption in sediment-water exchange of phosphate in North Sea continental margin sediments. Limnol. Oceanogr., 43, 832846.

Souchu P., Gasc A., Cahet G., Vaquer A., Collos Y. \& Deslous-Paoli J.M. 1997. - Biogeochemical composition of Mediterranean waters outside Thau Lagoon. Estuar. Coast. Shelf S., 44, 275-284.

Talling J.F. \& Driver D. 1963. - Some problems in the estimation of chlorophyll a in phytoplankton. Pages 142-146 in Proceedings of the Conference on Primary Productivity Measurement, Marine and Freshwater. Doty M.S. (ed). University of: USA Atomic Energy Commission, Division of Technical Information TID-7633, Hawaii.

ter Braak C.J.F. \& Šmilauer P. 2002. - CANOCO Reference manual and CanoDraw for Windows User's guide: Software for Canonical Community Ordination (version 4.5). Microcomputer Power, New York. 500 p.

Trobajo R., Quintana X.D. \& Sabater S. 2004. - Factors affecting periphytic diatom community in Mediterranean coastal wetland (Empordà wetlands, NE Spain). Arch. Hydrobiol., 160, 375-399.

Trobajo R., Quintana X.D. \& Moreno-Amich R. 2002. - Model of alternative predominance of phytoplankton-periphytonmacrophytes in lentic waters of Mediterranean coastal wetlands. Arch. Hydrobiol., 154, 19-40.

Valiela I., Teal J.M., Volkmann S., Shafer D. \& Carpenter E.J. 1978. - Nutrient and particulate fluxes in a salt marsh ecosystem: Tidal exchanges and inputs by precipitation and groundwater. Limnol. Oceanogr., 23, 798-812. 
